\title{
Performance of Upland Rice Varieties on Different Dates of Sowing in Kymore Plateau Region of Madhya Pradesh, India
}

\author{
Punit Tiwari", R.K. Tiwari, Amrita Tiwari and Jyoti Tiwari \\ Department of Agronomy, JNKVV, College of Agriculture, Rewa-486001, \\ Madhya Pradesh, India \\ *Corresponding author
}

\section{A B S T R A C T}

Keywords

Upland rice,

Kymore plateau,

Growth parameters

and economics

Article Info

Accepted:

04 March 2018

Available Online:

10 April 2018
An investigation entitled "Effect of sowing-dates on performance of different rice varieties under upland condition" was conducted at the Instructional Farm, College of Agriculture, Rewa (M.P.) under All India Coordinated Rice Improvement Project during the Kharif season of 2014. The experiment was laid out in split-plot design with four replications. The treatments comprised of three sowing dates i.e. $3^{\text {rd }} \mathrm{July}, 8^{\text {th }} \mathrm{July}$ and $13^{\text {th }} \mathrm{July}$ in main plots and 5 varieties i.e. Danteshwari, Vandana, IR-64, PS-3 and PS-5 in sub plots. The varieties were sown by direct-seeding. Among the varieties, PS-3 and then PS-5 performed better in this region. They resulted maximum growth parameters and grain yield up to 40.90 to $43.27 \mathrm{q} /$ ha with net income up to Rs. 48652 to $49778 /$ ha. The most optimum date of sowing of upland rice was $3^{\text {rd }}$ July which gave maximum growth parameters and grain yield up to $38.54 \mathrm{q} /$ ha with net income up to Rs. $41446 /$ ha. Thus, variety PS-3 or PS- 5 may be grown on $3^{\text {rd }}$ July is suitable to obtain maximum productivity and economical grain from rice under upland conditions of this region.

\section{Introduction}

The slogan "Rice is life" is most appropriate for India as this crop plays a vital role in our national food security and is a means of livelihood for millions of rural households. It is the most important staple food crop of India. The importance of rice in Asia is more pronounced as rice typically accounts $32 \%$ of cropped area in Asia. India is next to China in rice production. In India, rice is grown in an area of 44.6 million hectare with a production of 109.5 million tones and average productivity of 2.62 tons per hectare. Projection of India's rice production target for
2025 AD is 140 million tones which can be achieved only by increasing rice production by 2 million tons per year over the existing in the coming decade (Sridhar et al., 2011). In M.P. total area under rice production is 1.7 million ha in which only 223 thousands ha comes under irrigated situation. Total rice production is 1710 thousand tones in which 1313 thousand tones is from rained and 397 thousand tones is from irrigated area. The productivity of total rice area in M.P. is $1103 \mathrm{~kg} / \mathrm{ha}$ while irrigated area has $1273 \mathrm{~kg} / \mathrm{ha}$.

Direct-seeded rice provides an option to make paddy cultivation cost effective and eco- 
friendly, which saves not only labour required for transplanting but also helps to preserve natural resources especially underground water. Expansion in the irrigated area, introduction of early maturing rice cultivars, availability of selective herbicides for weed management together with increasing transplanting cost and declining profitability of transplanted rice production system have encouraged rice farmers to shift from transplanting to direct-seeding (Subbaiah et al., 1999). One of the critical aspects of direct seeding of rice is time of sowing. Sowing time is the major factor that determines the productivity of a crop. Optimum planting time for a crop is location specific. Optimum planting time worked out June 1-10 in Punjab (Gill et al., 2006), June 15 at New Delhi (Narayanaswamy et al., 1982) and June 5-15 at Cuttack (Chandra et al., 1991). Optimum sowing time thus needs to be standardized for every ago-ecological situation for success of direct seeded rice.

Gravois and Helms (1998) also showed that rice grain yields declined as seeding date was delayed. The sowing time of the rice crop is important for three major reasons. Firstly, it ensures that vegetative growth occurs during a period of satisfactory temperatures and high levels of solar radiation. Secondly, the optimum sowing time for each cultivar ensures the cold sensitive stage occurs when the minimum night temperatures are historically the warmest. Thirdly, sowing on time guarantees that grain filling occurs when milder autumn temperatures are more likely, hence good grain quality is achieved (Farrell et al., 2003).

Sowing date also has a direct impact on the rate of establishment of rice seedling (Tashiro et al., 1999). Rice varieties vary in their seedling vigor, weed competitiveness, submergence and drought tolerance, maturity duration, lodging resistance, affecting the resource utilization and productivity. Maximum numbers of total tillers are obtained when the crop was transplanted on 15 July, which decreased significantly with delayed planting on 30 July and 14 August (Patel, 1999). Early date of sowing is the best time of sowing for important properties such as maximum tillering, panicle initiation, heading date, number of tillers $\mathrm{m}^{-2}$, plant height and root length at panicle initiation and heading stage, chlorophyll content, number of days to panicle initiation and heading date, leaf area index, sink capacity, spikelet's/leaf area ratio, Number of grains per panicle, panicle length (cm), 1000-grain weight $(\mathrm{g})$, number of panicles $\mathrm{m}^{-2}$, five panicle weight $(\mathrm{g})$ and grain yield $\left(\mathrm{T} \mathrm{ha}^{-1}\right)$ (Khalifa, 2009). Looking to these facts in view, the present research was taken up. Objective of this experiment was to find out the Performance of rained rice varieties under different dates of sowing in kymore plateau region.

\section{Materials and Methods}

The field experiment was conducted in Kharif season of 2014 at Instructional Farm, College of Agriculture, Rewa (M.P.) under All India Coordinated Rice Improvement Project. The weather conditions which prevailed during Kharif 2014 were favorable for growth and development of the rice crop. Monsoon commences in the first week of July and terminated in the last week of September. The rainfall during the crop season was $814.2 \mathrm{~mm}$. Minimum and maximum temperature was 14.2 ${ }^{\circ} \mathrm{C}$ and $39.1^{0} \mathrm{C}$.

During this period, the relative humidity was maximum 62 to $100 \%$ and 22 to $80 \%$ was minimum. The experimental field was sandy clay loam in texture. It was normal electrical conductivity $(0.42 \mathrm{dS} / \mathrm{m})$ and just below neutral in reaction $(\mathrm{pH} 6.5)$. The organic carbon content was low (0.56-0.60\%) while medium in available Nitrogen and phosphorus 
contents 294-337, 18-36 respectively but high in potash content (314-611 kg/ha). The experiment was laid out in split-plot design with four replications. The treatments comprised of three sowing dates i.e. $3^{\text {rd }}$ July, $8^{\text {th }}$ July and $13^{\text {th }}$ July in main plots and 5 varieties, Danteshwari, Vandana, IR 64, PS-3 and PS-5 in sub plots. The varieties were sown by direct seeding in lines $20 \mathrm{~cm}$ apart keeping a seed rate of $30 \mathrm{~kg} / \mathrm{ha}$ on $3^{\text {rd }}, 8^{\text {th }}$ and $13^{\text {th }}$ July 2014. The seeds were treated with bavistin @ $2 \mathrm{~g} / \mathrm{kg}$ seed before sowing. Rice seeds were direct line sowed manually. The uniform dose of fertilizers ( $100 \mathrm{~kg} \mathrm{~N}, 60 \mathrm{~kg} \mathrm{P}_{2} \mathrm{O}_{5}$ and $40 \mathrm{~kg}$ $\mathrm{K}_{2} \mathrm{O} / \mathrm{ha}$ ) were applied in all the treatments. The crops were grown under recommended package of practices.

\section{Results and Discussion}

\section{Growth parameters}

The growth observations recorded periodically have exhibited many interesting architectural variations due to variation in sowing dates and varieties grown. The plant height and tillers $/ \mathrm{m}$ row length, increased steadily in all the treatments with the successive growth and development stages i.e. from 30 DAS to 90 DAS or up to harvest stage. These growth parameters were, in general, enhanced very fast between 30 to $60 \mathrm{DAS}$; thereafter the rise was normally slow up to 90 DAS or harvest stage. Thus up to the harvest stage, plant height ranged from 78.70 to $100.79 \mathrm{~cm}$ and tillers 51.46 to $65.22 / \mathrm{m}$ row length under the various treatments. The initial plant population per $m$ row length under each date of sowing was statistically uniform which might be due to fact that under each dates uniform number of seedlings per plot were planted. However, different varieties differed significantly with regard to plant population/m row length PS-3 registered significantly higher plant population (8.98/m row length) over the other varieties except PS-5. On the other hand Vandana recorded significantly lower plant population $(8.41 / \mathrm{m}$ row length). Such type of variation in this parameter might be due to variation in the vitality and truthfulness of seed which influenced their generation and emergence per unit area.

As regards with the effect of different sowing dates, earliest $3^{\text {rd }}$ July sowing produced significantly higher growth characters as compared to the sowing of crop on the later dates like plant height was $89.60 \mathrm{~cm}$ and tillers $59.53 / \mathrm{m}$ row length, but $13^{\text {th }}$ July sowing date reduced all these parameters almost up to significant extent i.e. $88.14 \mathrm{~cm}$ plant height, 51.46 tillers/m row length. In fact, there is a vital role of time of planting in paddy crop because of the variation in the duration, photo-sensitiveness, thermosensitiveness and vegetative lag period of the variety. The variation in the above mentioned growth parameters have also been reported by many research workers (Vange and Obi, 2006; Sreenivas et al., 2007; Rai and Kushwaha, 2008; Khalifa, 2009; Kerketta et al., 2010; Singh et al., 2012 and Limochi and Eskandari, 2013).

Amongst the varieties, PS-3 resulted in significantly higher number of tillers $(65.22 / \mathrm{m}$ row length whereas IR-64 recorded significantly higher plant height $(100.79 \mathrm{~cm})$. The number of tillers $/ \mathrm{m}$ row length $(44.84 \mathrm{~cm})$ was found significantly lower in case of Vandana. The other varieties also showed significant differences in all the growth characters under observation. Such type of variation in growth parameters among the different varieties might be owing to differences in their parental origin which caused variation in their genetically inheritance for such traits. The present funding corroborate with those of several researches (Ahn et al., 2000; Balaswamy and Kulkarni, 2001; Mukesh et al., 2008; Nawlakhe et al., 2009, and Walia et al., 2014) (Table 1). 
Table.1 Growth parameters of upland rice as influenced by dates of sowing and varieties

\begin{tabular}{|c|c|c|c|c|c|c|c|c|}
\hline \multirow[t]{2}{*}{ Treatments } & \multirow{2}{*}{$\begin{array}{c}\text { Plant } \\
\text { population } \\
\text { /m row } \\
\text { length (10 } \\
\text { DAS) }\end{array}$} & \multicolumn{4}{|c|}{ Plant height (cm) } & \multicolumn{3}{|c|}{$\begin{array}{c}\text { Number of tillers/m row } \\
\text { length }\end{array}$} \\
\hline & & $\begin{array}{c}25 \\
\text { DAS }\end{array}$ & $\begin{array}{c}50 \\
\text { DAS }\end{array}$ & $\begin{array}{c}75 \\
\text { DAS }\end{array}$ & $\begin{array}{c}\text { At } \\
\text { harvest }\end{array}$ & $\begin{array}{c}25 \\
\text { DAS }\end{array}$ & $\begin{array}{c}50 \\
\text { DAS }\end{array}$ & $\begin{array}{c}\text { At } \\
\text { harvest }\end{array}$ \\
\hline$\frac{\text { Dates of sowing: }}{3^{\text {rd }} \text { July }}$ & 8.80 & 30.26 & 59.57 & 85.10 & 89.60 & 17.59 & 58.55 & 59.53 \\
\hline $8^{\text {th }}$ July & 8.66 & 28.86 & 58.58 & 84.65 & 89.23 & 17.37 & 56.35 & 56.67 \\
\hline $13^{\text {th }}$ July & 8.60 & 28.38 & 57.92 & 83.77 & 88.14 & 16.45 & 50.94 & 51.46 \\
\hline S.Em+ & 0.08 & 0.65 & 0.38 & 0.77 & 0.52 & 0.41 & 0.31 & 0.33 \\
\hline C.D.@ 5\% & NS & NS & NS & NS & NS & NS & 1.09 & 1.13 \\
\hline$\frac{\text { Varieties: }}{\text { Danteshwari }}$ & 8.64 & 26.24 & 57.67 & 86.87 & 92.87 & 17.15 & 52.68 & 53.10 \\
\hline Vandana & 8.41 & 26.95 & 62.44 & 91.20 & 98.63 & 13.75 & 44.27 & 44.84 \\
\hline IR-64 & 8.61 & 41.33 & 77.96 & 98.18 & 100.79 & 17.75 & 55.19 & 56.12 \\
\hline PS-3 & 8.98 & 26.04 & 47.33 & 72.58 & 78.70 & 18.66 & 64.61 & 65.22 \\
\hline PS-5 & 8.80 & 25.25 & 47.33 & 73.70 & 79.69 & 18.36 & 59.64 & 60.16 \\
\hline S.Em+ & 0.08 & 0.87 & 0.54 & 0.66 & 0.57 & 0.46 & 0.60 & 0.52 \\
\hline C.D.@ @ $5 \%$ & 0.24 & 2.49 & 1.54 & 1.89 & 1.64 & 1.32 & 1.72 & 1.49 \\
\hline Interaction & NS & NS & NS & NS & NS & NS & NS & NS \\
\hline
\end{tabular}

Table.2 Yield and Economical gain upland rice as influenced by dates of sowing and varieties

\begin{tabular}{|c|c|c|c|c|c|}
\hline Treatments & $\begin{array}{l}\text { Grain yield } \\
\text { (q/ha) }\end{array}$ & $\begin{array}{l}\text { Straw yield } \\
\text { (q/ha) }\end{array}$ & $\begin{array}{l}\text { Harvest } \\
\text { index }(\%)\end{array}$ & $\begin{array}{l}\text { Net income } \\
\text { (Rs./ha) }\end{array}$ & B: C ratio \\
\hline$\frac{\text { Dates of sowing: }}{3^{\text {rd }} \mathrm{July}}$ & 38.54 & 88.86 & 31.26 & 41446 & 3.13 \\
\hline $8^{\text {th }}$ July & 37.52 & 87.65 & 31.21 & 40379 & 3.08 \\
\hline $13^{\text {th }}$ July & 36.32 & 84.27 & 31.14 & 38024 & 2.96 \\
\hline S.Em \pm & 0.17 & 0.46 & 0.08 & - & - \\
\hline C.D.@ 5\% & 0.58 & 1.59 & NS & - & - \\
\hline$\frac{\text { Varieties: }}{\text { Danteshwari }}$ & 36.29 & 67.18 & 35.07 & 36330 & 2.87 \\
\hline Vandana & 28.96 & 58.53 & 33.14 & 25504 & 2.32 \\
\hline IR-64 & 38.38 & 70.42 & 35.41 & 39485 & 3.04 \\
\hline PS-3 & 43.27 & 108.84 & 28.35 & 49778 & 3.55 \\
\hline PS-5 & 40.90 & 129.66 & 24.05 & 48652 & 3.49 \\
\hline S.Em \pm & 0.48 & 1.75 & 0.27 & - & - \\
\hline C.D.@ 5\% & 1.38 & 5.01 & 0.78 & - & - \\
\hline Interaction & NS & NS & NS & - & - \\
\hline
\end{tabular}




\section{Productivity parameters}

Grain yield (38.54 q/ha) straw yield (88.86 $\mathrm{q} / \mathrm{ha})$ and harvest index (31.26\%) was maximum in case of earliest $3^{\text {rd }}$ July sowing date. The significantly lowest grain yield (36.32 q/ha) and straw yield (84.27 q/ha) was noted in case of late sowing date of $13^{\text {th }}$ July under upland conditions. The variety PS-3 produced highest grain $(43.27 \mathrm{q} / \mathrm{ha}$ ) but lower straw (108.84 q/ha). However, the reverse was true in case of PS-5 variety of rice. The grain yield was lower $(40.90 \mathrm{q} / \mathrm{ha})$ and straw yield was highest (129.66 q/ha). However, the harvest index was found maximum $(35.41 \%)$ from variety IR- 64, closely followed by Danteshwari (35.07\%). The significantly lowest grain yield (28.96 q/ha) and straw yield (58.53 q/ha) was recorded from Vandana variety. The variety IR-64 attained the third position with the productivity parameters.

\section{Economical gain}

Sowing on $3^{\text {rd }}$ July of upland rice proved most beneficial giving maximum net income up to Rs. 41446/ha with B: C ratio 3.13. The crop sown five days late on $8^{\text {th }}$ July reduced the net income by Rs. 1067/ha, then when sown ten days late on $13^{\text {th }}$ July, the net income reduced up to Rs. 3422/ha. In case of rice varieties, PS-3 proved its superiority by giving highest net income up to Rs. 49778/ha with B: C ratio 3.55 . However the second equally best variety was PS-5 giving net income up to Rs. 48652/ha with B: C ratio 3.49. The third best variety was IR-64 nearly giving net income up to Rs. 39.485/ha with B: C ratio 3.04. This was followed by Danteshwari and then Vandana giving lowest net income up to Rs. $25504 /$ ha in related to the crop productivity and the gross income received (Table 2).

Based on the research findings, it can be concluded that Among the dates of sowing of upland rice, $3^{\text {rd }}$ July proved the best giving maximum growth parameters, yield attributes and grain yield up to $38.54 \mathrm{q} / \mathrm{ha}$ with net income up to Rs. 41446/ha and Among the varieties, PS-3 and then PS-5 resulted in maximum growth parameters, yield attributes and grain yield up to 40.90 to $43.27 \mathrm{q} / \mathrm{ha}$ with net income up to Rs. 48652 to 49778/ha. Based upon the grain yield it can be concluded that varieties PS-3 or PS-5 may be grown on $3^{\text {rd }}$ July to obtain maximum productivity and economical grain from rice under upland conditions of this region.

\section{References}

Ahn D, Choi JS, Choi CD, Lee SP Choi BS and Lee SC. 2000. Effects of seeding dates for direct seeding on dry paddy on growth and yield of rice varieties in Youngnam region. Korean Journal of Crop Science. 45(3): 185-189.

Anonymous. 2014. Annual report. Department of Agriculture and Cooperation Ministry of Agriculture Government of India.

Balaswamy K and Kulkarni N. 2001. Influence of time of transplanting on the performance of certain scented rice varieties in Andhra Pradesh. Journal of Research ANGRAU. 29(2/3):98-101.

Chandra D, Moorthy BTS, Jha KP and Manna GB. 1991. Agronomic practices for augmenting rice (Oryza sativa) production in rained upland ecosystem of Orissa. Indian Journal of Agronomy. 36:313-21.

Gill MS, Kumar A and Kumar P. 2006. Growth and yield of rice (Oryza sativa) cultivars under various methods and time of sowing. Indian Journal of Agronomy. 51:123-27.

Gravois KA and Helms RS. 1996. Seeding rate effect on rough rice yield, head rice and total milled rice. Agronomy Journal. 88:82-84. 
Kerketta NK, Dwivedi SK, Shrivastava GK and Saxena RR. 2010. Rooting pattern and yield of rice under rained upland situation in Alfisol with different sowing dates and $\mathrm{P}$ and $\mathrm{K}$ levels. Current Advances in Agricultural Sciences. 2(2): 115-117.

Khalifa AABA 2009. Physiological evaluation of some hybrid rice varieties under different sowing dates. Australian Journal of Crop Science 3(3): 178-183.

Limochi K and Eskandari H. 2013. Effect of planting date on performance of flag leaf stomata and grain yield of rice cultivar. Internation Journal of Agronomy and Plant Production 4(4): 769-773.

Mukesh, Singh I, Pannu RK, Prasad D and Ram A. 2009. Effects of different transplanting dates on yield and quality of basmati rice (Oryza sativa) varieties. Chaudhary Charan Singh Haryana Agricultural University, Hisar.

Nawlakhe SM. Mankar DD, and Jiotode DJ. 2009. Performance of basmati type scented rice (Oryza sativa L.) cultivars under different dates of transplanting in eastern Vidarbha. Crop Research (Hisar). 37(1/3):158-160.

Rai HK and Kushwaha HS. 2008. Effect of planting dates and soil water regimes on growth and Yield of upland rice. Oryza - An International Journal on Rice. 45(2): 129-132.

Singh AK, Chandra N and Bharti RC. 2012. Effects of genotype and planting time on phonology and performance of rice (Oryza sativa L.). Vegetos 25(1):151156

Sridhar CJ, Ramchandappa BK, Nanjappa HV and Mavarkar NS. 2011. Effect of Genotypes, planting geometry and method of establishment on growth and yield of aerobic rice. Mysore journal of Agriculture Science. 45(3): 501-505.

Tashiro T, Saigusa M and Shibuya K. 1999. A Trial of No-tillage Direct Seeding of Rice (Oryza sativa L.) at Early Spring in Cold Climate Region in Japan. Japanese Journal of Crop Science 68(1): 146-150.

Vange T and Obi IU. 2006. Effect of planting date on some agronomic traits and grain yield of upland rice varieties. Sustainable Development on Agricultural Environment. 2(1):1-9.

Walia US, Walia SS, Sindhu and Nayyar S. 2014. Production of direct-seeded rice in relation to different dates of sowing and varieties in central Punjab. Journal of crop weed.10 (1):126-129

\section{How to cite this article:}

Punit Tiwari, R.K. Tiwari, Amrita Tiwari and Jyoti Tiwari. 2018. Performance of Upland Rice Varieties on Different Dates of Sowing in Kymore Plateau Region of Madhya Pradesh, India. Int.J.Curr.Microbiol.App.Sci. 7(04): 236-241. doi: https://doi.org/10.20546/ijcmas.2018.704.026 